Abstracta Iranica Iranica

Revue bibliographique pour le domaine irano-aryen

Volume 32-33 | 2013

Comptes rendus des publications de 2009-2010

\title{
Michaël G. Morony. Aramaeans in Iraq after the Muslim Conquest
}

\section{Christelle Jullien}

\section{Q OpenEdition}

1 Journals

Édition électronique

URL : http://journals.openedition.org/abstractairanica/40858

DOI : 10.4000/abstractairanica.40858

ISSN : 1961-960X

\section{Éditeur :}

CNRS (UMR 7528 Mondes iraniens et indiens), Éditions de l'IFRI

\section{Édition imprimée}

Date de publication : 1 décembre 2013

ISSN : 0240-8910

\section{Référence électronique}

Christelle Jullien, « Michaël G. Morony. Aramaeans in Iraq after the Muslim Conquest », Abstracta Iranica [En ligne], Volume 32-33 | 2013, document 338, mis en ligne le 01 juillet 2016, consulté le 26 septembre 2020. URL : http://journals.openedition.org/abstractairanica/40858 ; DOI : https://doi.org/ 10.4000/abstractairanica.40858

Ce document a été généré automatiquement le 26 septembre 2020.

Tous droits réservés 


\title{
Michaël G. Morony. Aramaeans in Iraq after the Muslim Conquest
}

\author{
Christelle Jullien
}

\section{RÉFÉRENCE}

Michaël G. Morony. Aramaeans in Iraq after the Muslim Conquest. Piscataway NJ, Gorgias Press, 2009, 12 p. (Analecta Gorgiana, 109).

Il s'agit de la réimpression en extrait des pages 169-180 du même ouvrage, augmenté d'une présentation sur le développement de l'araméen parmi les populations des empires sassanide, omeyyade puis abbasside, et sur l'histoire politique de cette région. L'intérêt est focalisé sur les relations entre araméens et arabes, spécialement en dehors des centres urbains.

\section{AUTEURS}

\section{CHRISTELLE JULLIEN}

CNRS, Mondes iranien et indien, Paris 